\title{
Vývoj hráčské struktury v družstvech ženské basketbalové Excelsior ligy se zaměřením na věk a státní př́íslušnost
}

\section{The development of player's structure in women's basketball teams of Excelsior league in terms age and nationality}

\author{
Emil Řepka, Petr Novotný \\ Pedagogická fakulta Jihočeské univerzity, České Budějovice
}

\begin{abstract}
Abstrakt
Studie je zaměřena na problematiku složeni družstev v české nejvyšši basketbalové soutěži - ženské basketbalové lize Excelsior - od sezóny 1998/99 do ročníku 2010/11. Sledovaný soubor hráček byl rozdělen do tři skupin: Češky do 20 let, Češky nad 20 let včetně, cizinky. Základní metodou šetření byla obsahová analýza herních statistik utkání - počet hráček, jejich věk a státní př́slušnost, počet odehraných minut, počet vstřelených bodi̊ a koeficient užitečnosti. Výsledky potvrdily předpokládaný nárůst počtu cizinek v jednotlivých družstvech a jejich stále se zvyšující vliv - v naši studii prezentovaný koeficientem užitečnosti hráček - na probíhající zápasy ženské basketbalové ligy. Trend začleněni do soutěžních zápasủ českých hráček mladšich než 20 let je nepř́mo závislý na počtu českých hráček staršich než 20 let. Naše předpoklady tak byly potvrzeny. Práce poukazuje svými výsledky na změny ve složení jednotlivých hráčských družstev.
\end{abstract}

\begin{abstract}
This article looks at the evolution of structure teams in the top Czech women's basketball competition - Excelsior league. Tracking period is since seasons 1998/99 to 2010/11. The cardinal method of this research is based on content analysis of game match statistics - these include the number of female players (their age), minutes played, points scored and coefficient of usefulness. The sample of players is classified into three groups (Czech players younger than twenty years, Czech players twenty years old and older, foreign players). The results confirm the expected increase of number of foreign players as well as continuously growing impact on the game, in our study presented a coefficient of utility players. The trend of integration into Czech female players younger than 20 years is inversely dependent on the number of Czech female players older than 20 years. Our assumptions were confirmed. The article refers to the change of the team constitution.
\end{abstract}

Klíčová slova: basketball; women's basketball league Excelsior; game statistics; national structure; team constitution.

Keywords: basketbal; ženská basketbalová liga Excelsior; herní statistika; národnostní struktura; složení družstva.

\section{ÚVOD}

Doby, kdy sport žen byl na okraji zájmu veřejnosti, jsou minulostí. Dnes ženy soutěží amatérsky i profesionálně v každém větším sportu. Míra jejich účasti obvykle klesá přímou úměrou s tendencí sportu $\mathrm{k}$ agresivitě a jeho kontaktní charakteristice. $\mathrm{V}$ týmových sportech je $\mathrm{v}$ popředí diváckého zájmu ženský basketbal a fotbal (viz nedávná světová mistrovství v těchto sportech v ČR a Německu). Základním rysem sportu je maximální výkon. Ten je žádaný a přitažlivý v nejširším měřítku. Jeho afinita ke sledování roste s mírou jeho úrovně. Nejvíce sledovaná je maximální úroveň, kterou představuje vrcholový sport. Sport se stal velmi dobře prodejným zbožím, a proto zejména do jeho vrcholové formy stále razantněji vstupují ekonomické aspekty. Naznačené př́stupy v očích divácké, ale někdy i odborné veřejnosti, odsouvaly ženský sport do druhého plánu vzhledem k mužským soutěžím. Praxe ukazuje, že tomu tak není. I v ekonomické oblasti to potvrzují odborná zjištění např. (Brown \& Jewell, 2006; Hallmark \& Armstrong, 1999).

V současné době registrujeme okolo nás genderově orientované studie. My tento problém chápeme 
emancipačně. Výše uvedené je jeden z důvodů, proč se problematikou ženského vrcholového basketbalu zabýváme. Druhým důvodem je, že podobnou studii jsme zpracovali na srovnatelné hráčské úrovni u mužů v České republice (blíže Řepka \& Bubák, 2011).

\section{PROBLÉM}

Smyslem této studie, je zmapovat vývoj struktur družstev v české ženské nejvyšší basketbalové soutěži od sezóny 1998/1999 do sezony 2010/2011 a poukázat na problematiku většího zapojování hráček z ciziny do týmů a utkání. Na klubové evropské scéně bez cizinek uspět asi nelze. Na počátku tisíciletí se v českém ženském basketbalu prosazovala silná generace mladších hráček. Úspěchy na reprezentační úrovni na sebe nenechaly dlouho čekat (např. ME 2003 v Řecku 2. místo; ME 2005 Turecko zlatá medaile; MS 2010 v ČR 2. místo). Nejvyšší česká ženská soutěž získala větší renomé a v lize začínáme nacházet více zahraničních hráček. Chceme zjistit, jaký je současný stav a trend tohoto jevu, který je úzce spojen se zapojením mladší generace českých hráček do zápasů nejvyšší soutěže. V širším kontextu i na dopad a návaznost na zmiňovanou úspěšnou generaci národní reprezentace českých basketbalistek. Cílem naší práce je zjistit jaký je podíl, přínos a vytíženost českých hráček do dvaceti let, hráček nad dvacet let a cizinek v ženské nejvyšší basketbalové soutěži (dále ŽBL) od sezóny 1998/1999 po současnost.

\section{METODIKA}

Výzkumný soubor tvoří hráčky nejvyšší české ženské basketbalové soutěže (ŽBL) od sezóny 1998/1999 do 2010/2011. Statistickými jednotkami jsou hráčky, které odpovídají kritériím jednotlivých kategorií této studie. Z těchto jednotek jsou určeny statistické znaky - věk, státní prríslušnost, počty odehraných minut, vstřelených bodů a koeficient užitečnosti. Hlavní výzkumnou metodou je analýza pramenů. Zdrojem informací jsou technické zápisy o utkání ŽBL od sezony 1998/1999 - 2010/2011(www.cbf.cz, 2011 a 2012).

V současnosti (březen 2012) se evidují statistiky nejen v nejvyšších basketbalových soutěžích- Národní basketbalová liga mužů (dále NBL) a v ŽBL, ale také v první lize mužů a žen a extraligové soutěži juniorů a juniorek. Naše práce využila tyto statistické údaje ze ŽBL, z oficiálního webu České basketbalové federace (dále ČBF), které jsou od sezony 1998/1999 plně k dispozici. Technické záznamy z utkání se zapisují př́mo, v jeho průběhu, do programu FIBA LIVE STATS, který tato data okamžitě zpracovává a předává výsledky na internet. Tento program ovládá osoba oprávněná Českou basketbalovou federací. Zkratky a vysvětlivky statistických kategorií technického zápisu jsou dostupné na www.cbf.cz, (retrieved 1.3.2012 from World Wide Web). Sledované statistické znaky jsou:

- $\quad$ Počet hráček

- $\quad$ Počet odehraných minut

- $\quad$ Počet vstřelených bodů

- $\quad$ Koeficient užitečnosti

Statistický znak - koeficient užitečnosti (rating) hráče v utkání je definován podle ČBF (www.cbf.cz, retrieved 1.7.2011 from World Wide Web). Statistický znak - počet odehraných minut. Za minimální hrací dobu budeme považovat splnění minimálního limitu $5 \%$ podílu z maximální možné doby na jednu hráčku v sezoně. Do výpočtů tak nejsou započítána prodloužení a hlavně také všechny hráčky, které nastoupily do zápasů ŽBL.

Limit jsme zvolili proto, aby se jednalo jen o hráčky patřící delší čas do týmu a neplnily v něm pouze epizodní roli.

Přiklad: Družstvo Přerova odehrálo v sezoně 1998/1999 30 zápasů. Basketbalové utkání trvá 40 minut. Do našich statistik proto započítáme každou hráčku, která odehrála více než 60 minut $(40 * 30 * 0,05=60)$.

Skupiny sledovaných hráček ŽBL:

$\begin{array}{ll}\text { - } & \text { Češky pod } 20 \text { let } \\ \text { - } & \text { Cizinky } \\ & \text { Češky nad } 20 \text { let }\end{array}$

Př́klad: Češky pod 20 let - např. v sezoně 1998/1999 započítáváme všechny hráčky, které jsou narozeny po prvním červnu 1978. V sezoně 99/00 hráčky narozené

po datu 1. 6. 1979 atd.

Tuto hranici pro zařazení do věkové skupiny, volíme z důvodů nadstavbové části basketbalové ligy, která končí v měsíci květnu a do statistik tak započítáme vyšší počet mladých hráček. Cizinkou rozumíme hráčku, 
která nemá občanství ČR.

Pro lepší orientaci uvádíme sjednocené názvy všech družstev, která zasáhla do soutěžního ročníku ŽBL v rozmezí sezon 1998/1999 - 2010/2011.

Celkem bylo započítáno 20 basketbalových klubů.

- BA Sparta

- $\quad$ Basket Slovanka - Slovanka Tábor, Slovanka Mladá Boleslav, Slovanka Chomutov

- $\quad$ BK Kompresory Praha

- $\quad$ Brno (Královo Pole) - Lachema Brno, Basketbal SK Královo Pole, Valosun

Brno, VALOSUN Brno

- Brno (Žabovřesky) - BK IMOS Gambrinus Žabovřesky, BK Gambrinus Brno - Žabovřesky, BK Gambrinus BVV Brno, Gambrinus Brno, Gambrinus JME Brno, Gambrinus Sika Brno, Frisco Sika Brno

- Hradec Králové - Sokol Amaranth Hradec Králové, TJ VČP Sokol Hradec

Králové, Sokol VČP Hradec Králové, Sokol Hradec Králové

- Karlovy Vary - BK BLEX Dermacol Karlovy Vary, BK Lokomotiva Karlovy Vary

- $\quad$ Kralupy nad Vltavou - BK Kaučuk Kralupy n. Vltavou

- $\quad$ Libochovice - BC Libochovice A

- $\quad$ Olomouc - SK UP Olomouc

- $\quad$ Pardubice - BK Pliska Studánka Pardubice

- $\quad$ Přerov - SBC Hanácká kyselka Přerov, Basketsport EMOS Přerov

- Sparta Praha - BK Mottl Glas Praha, Quelle Sparta, BLC Sparta Praha, Kooperativa Sparta Praha, Sparta Praha

- $\quad$ Strakonice - BK ČZ Strakonice, ČZ MUS Strakonice, BK MUS ABplus Strakon ice, BK Appian ABplus Strakonice, BK Czech coal Aldast Strakonice

Tábor - BK Tábor

- $\quad$ Trutnov - BK Loko Texlen Trutnov, BK Loko Texlen Trutnov SSŽ, BK VČE Loko Trutnov SSŽ, BK Loko Trutnov, Kara Trutnov

- USK Praha - USK Praha, USK Blex K. V. Praha, USK Blex KV Praha, USK Blex Praha, ZVVZ USK Praha

Ústí nad Labem - PEML Ústí nad Labem, BK Skřivánek Ústí nad Labem

VŠ Praha

Žd'ár nad Sázavou - TJ ŽĎAS Žd'ár nad Sázavou

\section{VÝSLEDKY A DISKUSE}

Vzhledem $\mathrm{k}$ omezeným prostorovým možnostem uvádíme $\mathrm{v}$ našem příspěvku přehled dat formou tabulek z počátečního a konečného roku sledování. Viz tabulky 1 a 2. Ve vybraných ukazatelích je kontinuita uvedena v grafické formě. Blíže obrázek 1, 2, 3, 4 a 5.

Vývoj složení družstev ženské basketbalové ligy z hlediska státní př́islušnosti a věku zachycuje Obrázek 1. Od roku 1998/99, kdy v české nejvyšší basketbalové ženské soutěži bylo jen 8 cizinek, jejich počet lineárně stoupá až do sezóny 2008/09 (viz Obrázek 1 a 2). V této sezóně za sledované období dosahuje vrcholu. Cizinky jsou zastoupeny v hráčském kádru ŽBL 25,4\% tj. fakticky 31 hráček. Při pohledu na Obrázek 1 věkové kategorie českých hráček jsou ve vzájemném vztahu téměř nepřímo úměrné. Nejmarkantněji je to vidět $v$ sezóně 2000/2001, kdy hraje v ŽBL nejvíce českých hráček starších než 20 let (66,7\%), naopak hráček do 20-ti let nejméně jenom 26\%. Nejvíce hráček do 20-ti let hrálo ŽBL v sezóně 2003/2004 - 41,2\%. Naopak tato sezóna pro hráčky nad 20 let a jejich účast na hře patří $\mathrm{k}$ těm nejnižším (46,5\%). Propojený nárůst a pokles $\mathrm{v}$ těchto dvou věkových skupinách je evidentní v každé sezóně od roku 1998/99 do sezóny 2010/2011. Vývojové křivky mají zrcadlový průběh. Počínaje sezónou 2003/04 (s výjimkou sezóny 2005/06) věková skupina hráček starších než 20 let klesla svým objemem pod 50\%. Poslední ze sledovaných herních sezón (2010/11) s sebou přinesla velmi výrazný vzestup hráček v kategorii nad 20 let. Vrací se na hodnotu téměř shodnou s rokem 2000/01 (opět v kontrastu k mladým českým hráčkám). Podíl cizinek stoupal téměř plynule až do sezóny 2008/09. Od herního roku 2009/10 se počet zahraničních hráček snižuje. U hráček do 20-ti let je patrný pokles až v sezóně 2010/11, kdy naopak o 17\% více ve svůj prospěch, získávají hráčky starší než 20-let, a dosahují svého druhého maxima ve sledované periodě. Pro zajímavost uvádíme srovnání nejvyšších soutěží v basketbalu v ČR u žen a u mužů 
(Obrázek 2.). Vidíme, že trend je u obou stejný. Absolutně, u mužů však podstatně vyšší.

Obrázek 1. Procentuální zastoupení věkových skupin českých hráček a cizinek v ženské basketbalové lize.

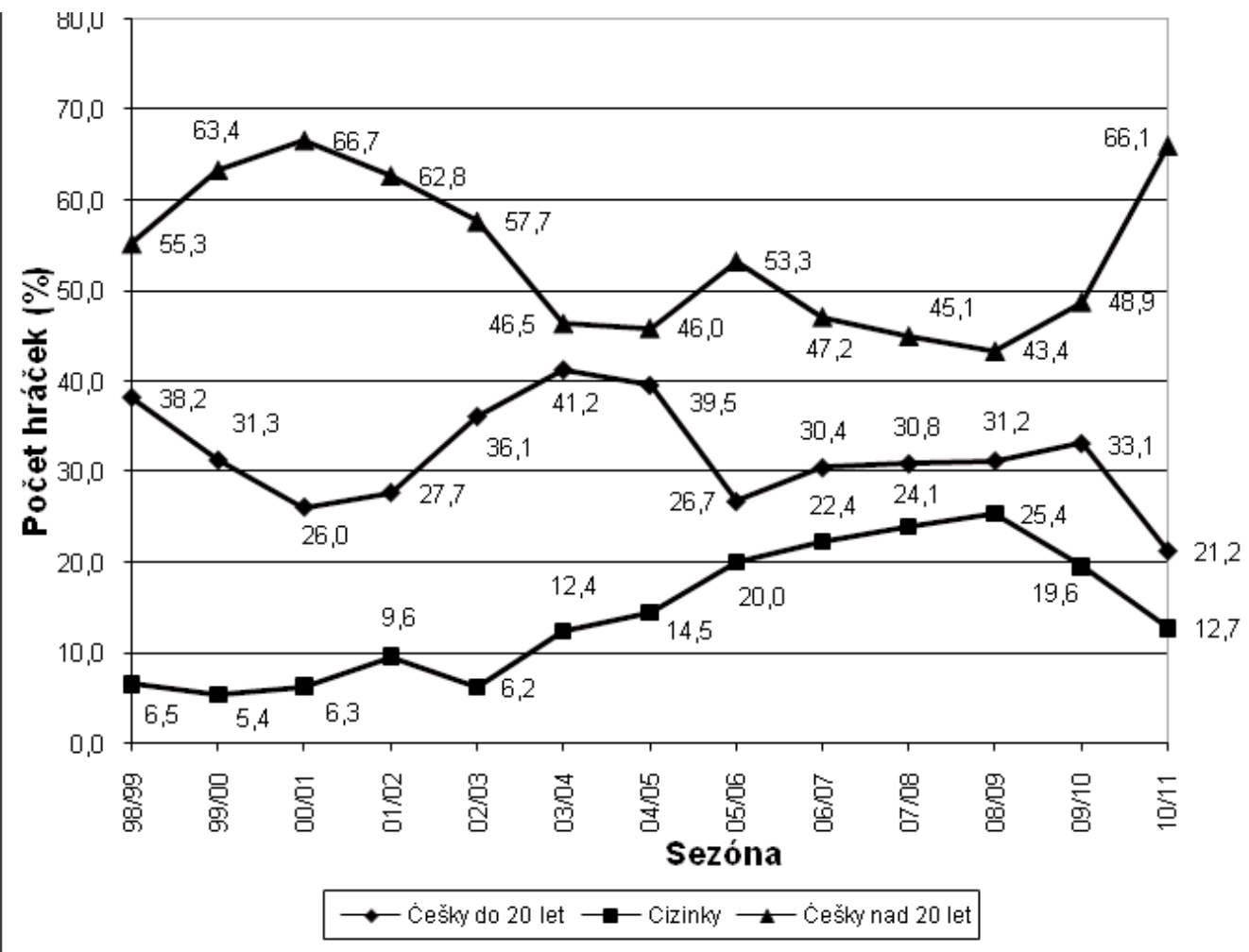

Obrázek 2. Zastoupení cizinek a cizinců v hráčském kádru ŽBL a NBL.

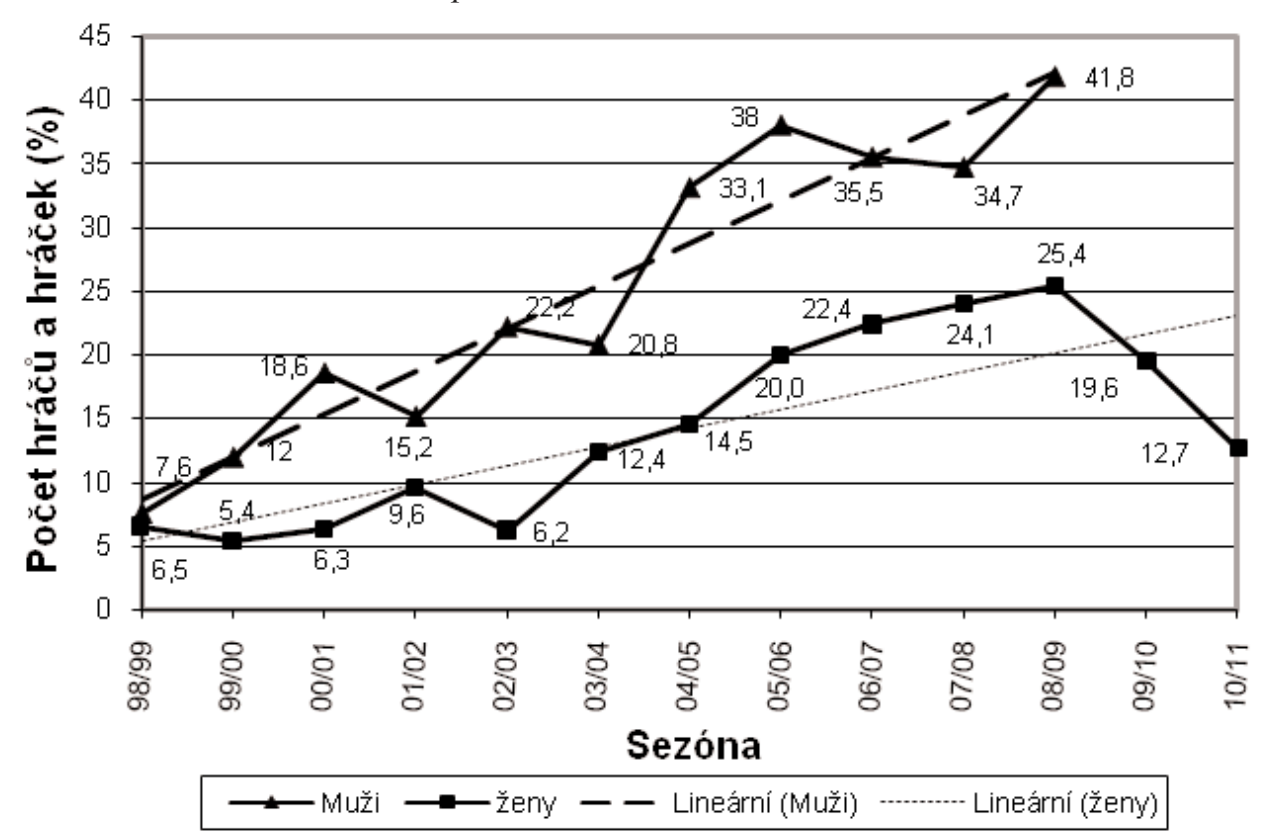


Obrázek 3. Rating hráček ve sledovaných skupinách.

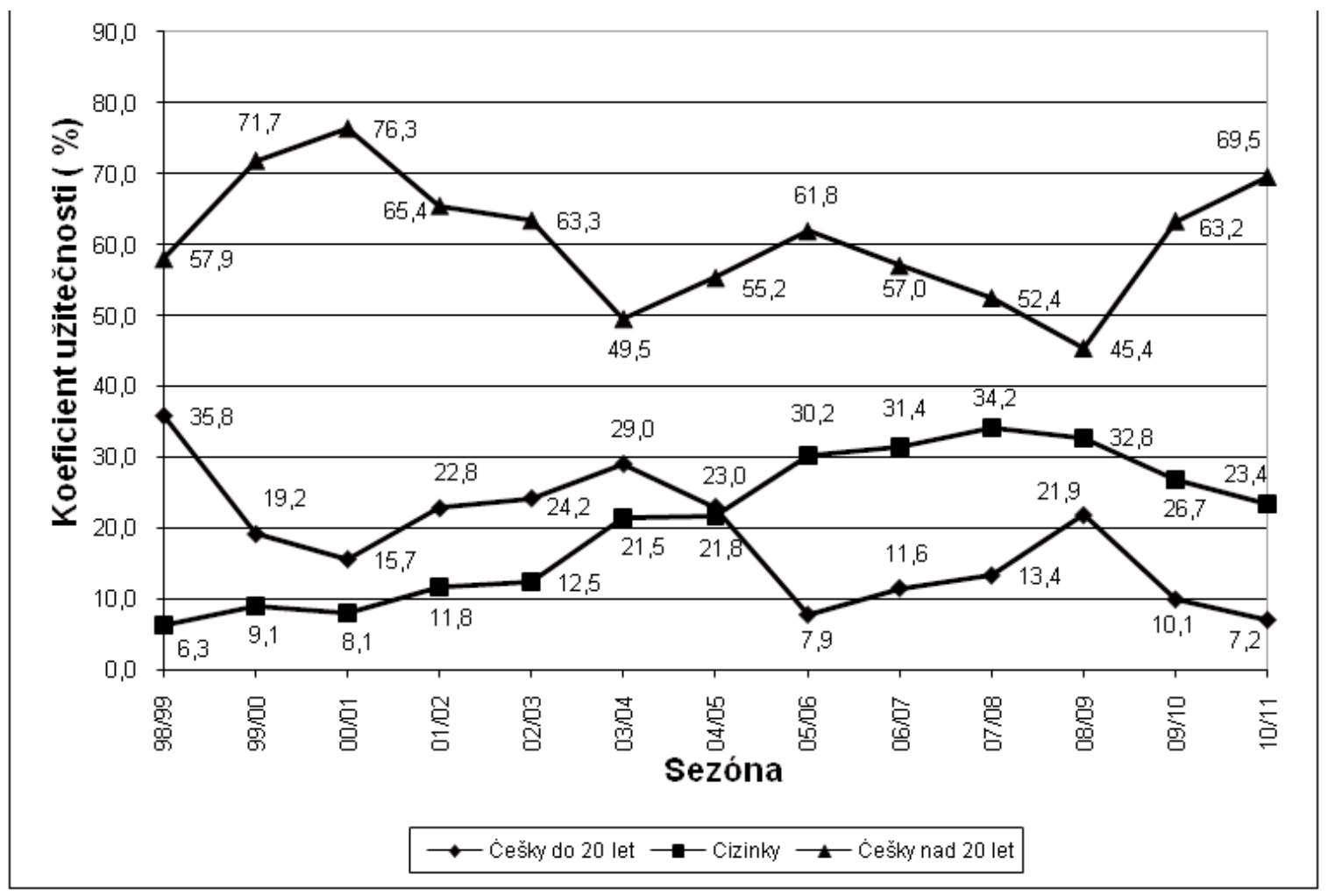

Tabulka 1. Statistika sezóny 1998/1999

Hráčky mladši 20-ti let jsou narozeny po 1.6.1978

\begin{tabular}{|c|c|c|c|c|c|c|c|c|c|c|c|c|c|}
\hline \multicolumn{2}{|c|}{ Umístění týmu } & 1. & 2. & 3. & 4. & 5. & 6. & 7. & 8. & 9. & 10. & & \\
\hline \multicolumn{2}{|l|}{ Tým } & Žabovřesky & Přerov & Trutnov & Kralupy & $\begin{array}{c}\text { Lachema } \\
\text { Brno }\end{array}$ & $\begin{array}{c}\text { Karlovy } \\
\text { Vary }\end{array}$ & USK & Žd'ár & Strakonice & Libochovice & & \\
\hline \multicolumn{2}{|c|}{ Počet zápasů } & 30 & 34 & 33 & 32 & 32 & 33 & 34 & 34 & 34 & 34 & & \\
\hline \multicolumn{2}{|c|}{$5 \%$ minut na hráčku } & 60 & 68 & 66 & 64 & 64 & 66 & 68 & 68 & 68 & 68 & $\Sigma$ & $\%$ \\
\hline \multirow{3}{*}{ 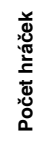 } & Celkem & 12 & 12 & 11 & 13 & 12 & 13 & 13 & 10 & 15 & 12 & 123 & \\
\hline & Češky >20 let & 1 & 1 & 9 & 3 & 6 & 2 & 7 & 9 & 7 & 2 & 47 & 38,21 \\
\hline & Češky<20 let & 7 & 10 & 2 & 10 & 6 & 9 & 5 & 1 & 8 & 10 & 68 & 55,28 \\
\hline \multirow{4}{*}{ 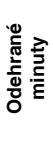 } & Celkem & 5973 & 6638 & 6436 & 6321 & 6321 & 6593 & 6721 & 6671 & 6792 & 6785 & 62251 & \\
\hline & Češky>20 let & 496 & 657 & 1130 & 826 & 3027 & 471 & 4579 & 6596 & 1638 & 764 & 20184 & 30,93 \\
\hline & Cizinky & 1377 & 540 & 0 & 0 & 0 & 487 & 282 & 0 & 0 & 0 & 2686 & 4,12 \\
\hline & Češky<20 let & 4100 & 5441 & 5306 & 5495 & 3294 & 5635 & 1860 & 75 & 5154 & 6021 & 42381 & 64,95 \\
\hline \multirow{3}{*}{ 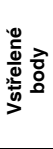 } & Celkem & 3077 & 2541 & 2010 & 2271 & 2235 & 2248 & 2204 & 2086 & 1835 & 2139 & 22646 & \\
\hline & Cizinky & 748 & 176 & 0 & 0 & 0 & 202 & 111 & 0 & 0 & 0 & 1237 & 5,46 \\
\hline & Češky<20 let & 2007 & 2063 & 1858 & 1998 & 1160 & 1907 & 384 & 20 & 1512 & 1962 & 14871 & 65,67 \\
\hline \multirow{4}{*}{ 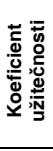 } & Celkem & 3897 & 2358 & 1811 & 2166 & 1829 & 1814 & 2015 & 1924 & 1313 & 1022 & 20149 & \\
\hline & Češky>20 let & 419 & 332 & 1631 & 207 & 762 & 107 & 1572 & 1914 & 179 & 83 & 7206 & 35,76 \\
\hline & Cizinky & 879 & 107 & 0 & 0 & 0 & 190 & 99 & 0 & 0 & 0 & 1275 & 6,33 \\
\hline & Češky<20 let & 2599 & 1919 & 180 & 1959 & 1067 & 1517 & 344 & 10 & 1134 & 939 & 11668 & 57,91 \\
\hline \multirow{4}{*}{\multicolumn{2}{|c|}{ 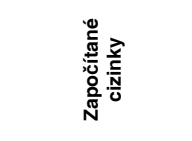 }} & Berukstiene & Bakič & & & & Gureeva & Gonsalves & & & & & \\
\hline & & Marilova & & & & & Mc Combs & & & & & & \\
\hline & & Stepanova & & & & & & & & & & & \\
\hline & & Branzova & & & & & & & & & & & \\
\hline
\end{tabular}




\begin{tabular}{|c|c|c|c|c|c|c|c|c|c|c|c|c|c|}
\hline \multicolumn{2}{|c|}{ Umístění týmu } & 1. & 2. & 3. & 4. & 5. & 6. & 7. & 8. & 9. & 10. & & \\
\hline \multicolumn{2}{|l|}{ Tým } & USK & Brno & Strakonice & Valosun & Slovanka & Trutnov & Karlovy Vary & $\begin{array}{l}\text { Hradec } \\
\text { Králové }\end{array}$ & VŠ Praha & Pardubice & & \\
\hline \multicolumn{2}{|c|}{ Počet zápasů } & 32 & 30 & 40 & 38 & 29 & 29 & 31 & 31 & 28 & 28 & & \\
\hline \multicolumn{2}{|c|}{ 5\% minut na hráčku } & 64 & 60 & 80 & 76 & 58 & 58 & 62 & 62 & 56 & 56 & $\Sigma$ & $\%$ \\
\hline \multirow{3}{*}{ 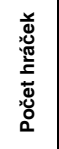 } & Celkem & 12 & 10 & 11 & 11 & 12 & 11 & 11 & 14 & 12 & 14 & 118 & \\
\hline & Češky>20 let & 0 & 3 & 1 & 0 & 2 & 4 & 1 & 5 & 4 & 5 & 25 & 21,19 \\
\hline & Češky<20 let & 8 & 3 & 10 & 10 & 10 & 6 & 6 & 9 & 8 & 8 & 78 & 66,10 \\
\hline \multirow{4}{*}{ 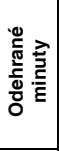 } & Celkem & 6217 & 5944 & 7905 & 7582 & 5778 & 5768 & 5994 & 6221 & 5565 & 5454 & 62428 & \\
\hline & Češky>20 let & 0 & 671 & 107 & 0 & 664 & 1284 & 339 & 2038 & 1278 & 1293 & 7674 & 12,29 \\
\hline & Cizinky & 2182 & 3893 & 0 & 675 & 0 & 828 & 1970 & 0 & 0 & 487 & 10035 & 16,07 \\
\hline & Češky<20 let & 4035 & 1380 & 7798 & 6907 & 5114 & 3656 & 3685 & 4183 & 4287 & 3674 & 44719 & 71,63 \\
\hline \multirow{3}{*}{ 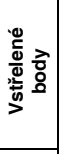 } & Celkem & 2925 & 2580 & 2797 & 2721 & 2024 & 2190 & 2018 & 2017 & 1862 & 1569 & 22703 & \\
\hline & Cizinky & 1235 & 1778 & 0 & 209 & 0 & 411 & 791 & 0 & 0 & 169 & 4593 & 5,46 \\
\hline & Češky<20 let & 1690 & 521 & 2781 & 2512 & 1828 & 1367 & 1141 & 1382 & 1474 & 1042 & 15738 & 65,67 \\
\hline \multirow{4}{*}{ 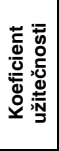 } & Celkem & 3545 & 3064 & 2901 & 2722 & 1880 & 1857 & 1862 & 1676 & 1634 & 930 & 22071 & \\
\hline & Češky>20 let & 0 & 319 & 1 & 0 & 109 & 246 & 60 & 431 & 261 & 158 & 1585 & 7,18 \\
\hline & Cizinky & 1555 & 2315 & 0 & 142 & 0 & 378 & 678 & 0 & 0 & 90 & 5158 & 23,37 \\
\hline & Češky<20 let & 1990 & 430 & 2900 & 2580 & 1771 & 1233 & 1124 & 1245 & 1373 & 682 & 15328 & 69,45 \\
\hline \multirow{4}{*}{\multicolumn{2}{|c|}{ 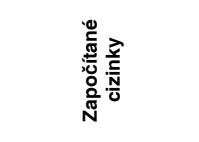 }} & Maltsi & Eldebrink & & Mračnová & & Mišurová & Hrabáková & & & Quintana & & \\
\hline & & Milton-Jones & Ford & & & & & Kovalová & & & & & \\
\hline & & Vajda & Halvarsson & & & & & Magerčiaková & & & & & \\
\hline & & Whalen & Škerovič & & & & & Paige & & & & & \\
\hline
\end{tabular}

Dalším statistickým znakem, který jsme sledovali, je herní rating hráčky. Je to poměrně objektivní ukazatel herního výkonu jednotlivce, který se snaží postihnout herní aspekty hráčky v basketbalu. Je vyjádřen koeficientem užitečnosti. Jeho míru a vývoj pro sledovanou periodu a výzkumný soubor ukazuje Obrázek 3. Průběh relativních hodnot koeficientu užitečnosti je podobný vývoji v jednotlivých věkových skupinách (Obrázek 1.). Není však identický. Rozdílnost spočívá v míre obou statistických znaků. Např́klad sezóna 2000/01 u českých hráček. Zastoupení věkové skupiny českých hráček starších jak 20 let má v tomto roce hodnotu 66,7\%, koeficient užitečnosti, ale o $10 \%$ vyšší $(76,3 \%)$.

Věková skupina mladých hráček do dvaceti let je zastoupena $26 \%$, jejich koeficient užitečnosti je $15,7 \%$. Dalo by se říci, že hráčky nad 20 let jsou o $20 \%$ v tomto kritériu efektivnější než jejich spoluhráčky mladší než 20 let. V tomto srovnávání má větší váhu, koeficient užitečnosti vztahovat k hracímu času háček. Preference zkušenějších hráček v soutěži je z pohledu trenérů pochopitelná. V kategorii cizinky je vývoj od českých hráček odlišný. V sezónách 1998/99 až 2002/03 jsou rozdíly v řádu desetin a jednotek \%. Od sezóny 2003/04 se tento rozdíl přiblí̌il 10\% a výše. Možným vysvětlením je nižší hráčská kvalita zahraničních hráček v ŽBL v letech 1998-2003. Trend prosazení se zahraničních hráček (viz Obrázek. 4), je pro ně progresivní. Možným vysvětlením (mimo jiné) jsou i jejich somatické předpoklady vzhledem k herní pozici (e.g. Carter, Ackland, Kerr, \& Stapff, 2005; Ackland, Schreiner, \& Kerr, 1997). Kondicionál je použit záměrně, protože somatické charakteristiky jsme v našem souboru nezjišt’ovali. Náhled na účast zahraničních hráček v české nejvyšší soutěži není jednoznačný. Má, jako každý jev, své klady a zápory. Je nutné si uvědomit, že ovlivnění zejména mládeže sportovními idoly je značné a má na ni výchovný dopad. Nejen na ni, ale i na samotné hráčky ( Yep, 2012). Participace zahraničních hráček na herním výkonu basketbalového družstva žen je evidentní a pozitivní (viz koeficient úspěšnosti). Má širší souvislosti spojené s úspěšností družstva a interpersonálními vztahy v týmu (cf. Gomez, Lorenzo, Sampaio, \& Ibanez, 2006; Wlazlo, 2007). 
Obrázek 4. Podíl jednotlivých hráčských kategorii na vstřelených bodech.

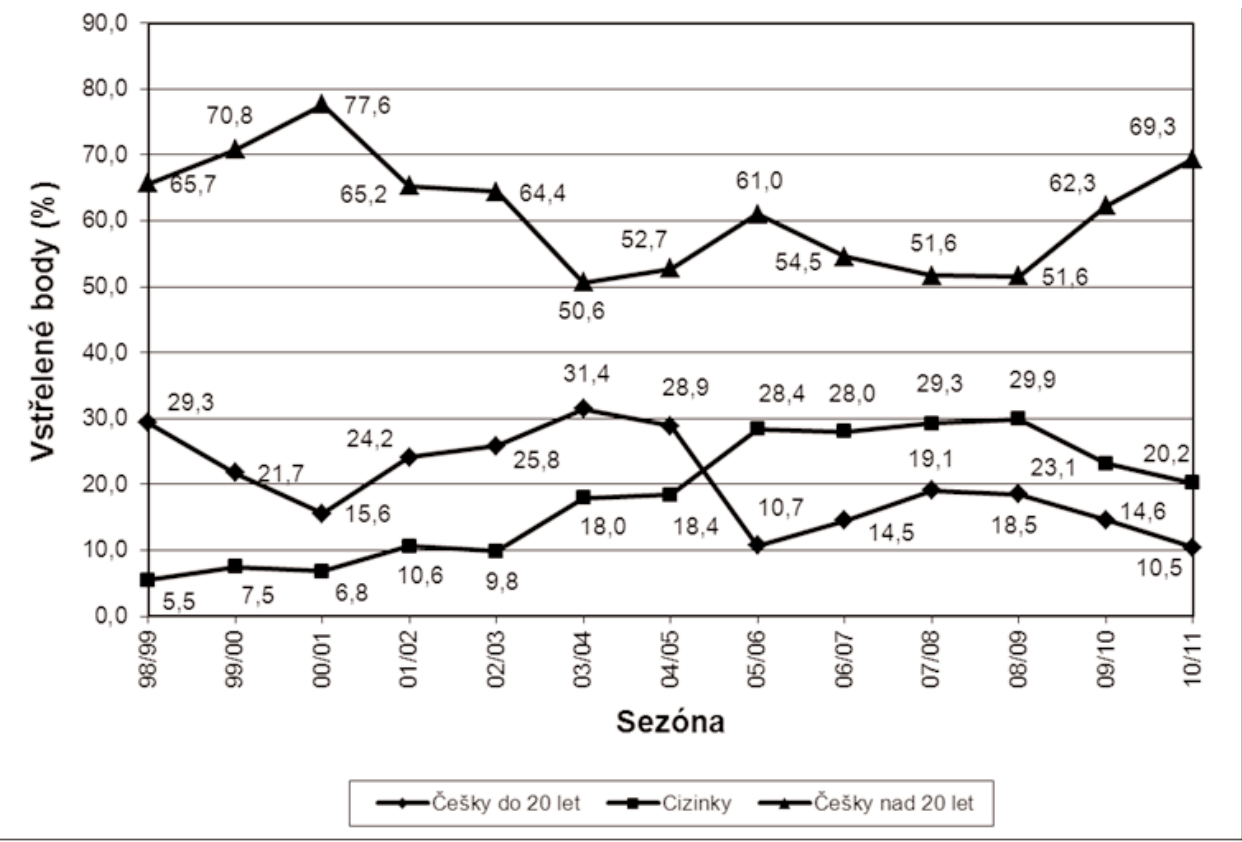

Pro úplnost uvádíme výsledky sledovaných hráčských skupin ve vstřelených bodech (Obrázek 4.) Střelba je jednou z položek s velkou váhou v ratingu hráček. Proto nepřekvapuje shodný vývoj těchto dvou ukazatelů (cf. Obrázek 3. a 4.).

Obrázek 5. Zastoupení českých hráček a cizinek v top 20 jednotlivých sezón sledované periody.

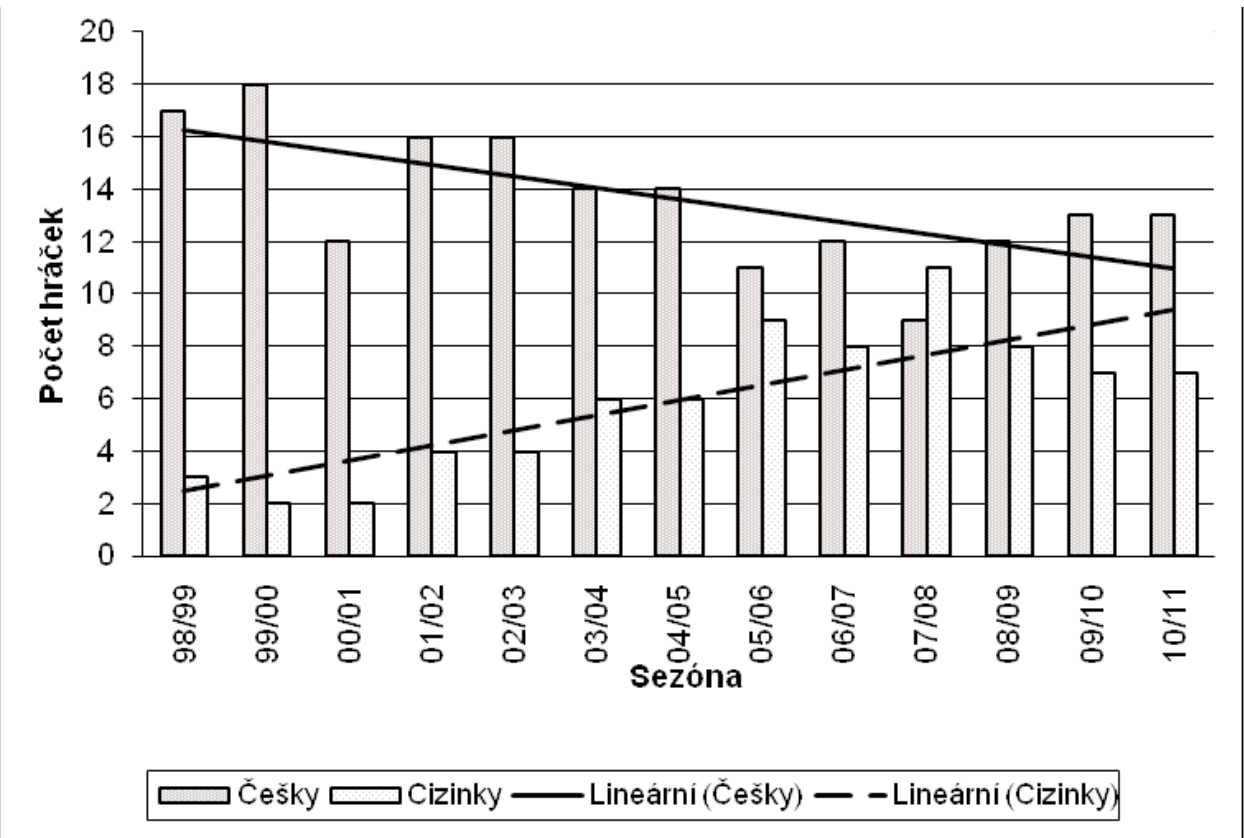

\section{ZÁVĚR}

Hlavní zastoupení v ženské basketbalové lize Excelsior v započítaných třinácti sezonách mají české hráčky starší než 20 let. Počet zahraničních hráček od sezóny 1998/99 progresivně stoupal ( z 6,5\% na 25,4\%) až do sezóny 2008/09. Míru zapojení hráček mladších než 20 let do soutěžních zápasů, spíše ovlivňuje kategorie 
českých hráček nad 20 let než kategorie cizinky. Z hlediska koeficientu užitečnosti jsou starší české hráčky o $20 \%$ efektivnější než jejich české spoluhráčky mladší než 20 let. Cizinky překročily hranici rozdílu mezi počtem hráček a efektivitou o 10 \% ve prospěch statistického znaku efektivity až v sezóně 2005/06. Jejich herní efektivita vyjádřená koeficientem užitečnosti má vzestupný trend ve všech sledovaných sezonách. Dochází $\mathrm{k}$ nárůstu počtu zahraničních hráček a hráčů v českých nejvyšších basketbalových soutěžích.V mužské soutěži výrazněji.

\section{Literatura}

Ackland, T.R., Schreiner, A.B., \& Kerr, D.A. (1997). Absolute size and proportionality chacteristics of World Champinonship female basketball players. Journal of Sports Sciences, 15(5), 485 - 490. ISSN: 1466-477X.

Brown, R.W. \& Jewell, R.T. (2006). The marginal revenue of a women's college basketball player. Industrial Relations, 45(1), 96 - 101. ISSN: 00198676.

Carter, J.E.L., Ackland T.R., Kerr, D.A.,\& Stapff, A.B. (2005). Somatotype and size of elite female basketball players. Journal of Sports Sciences, 23(10), 1057-1063. ISSN: 1466-477X.

Gomez, M.A., Lorenzo,A., Sampaio, J.,\& Ibanez, S.J. (2006). Differences in game-related statistics between winning and losing teams in women's basketball. Journal of Human Movement Studies, 51(5), 357 - 369. ISSN: 0367297.

Hallmark, J.R.\& Armstrong, R.N. (1999). Gender equity in televised sports: A comparative analysis of men's and women's NCAA division I basketball championships broadcast, 1991 - 1995. Journal of Broadcasting \& Electronic Media, 43(2), 222-235. ISSN: 1550-8151.

Řepka, E. \& Bubák, J. (2011). Vývoj hráčské struktury a podíl cizinců na herním výkonu družstev extraligy mužů v basketbalu v České republice. Studia Sportiva, 5(2), 115 - 124. ISSN: 1802-7679.

Wlazlo, E. (2007). Interpersonal relations in women basketball teams. Human Movement, 8(1), 32 - 38. ISSN: 17323991.

Yep, K.S. (2012). Peddling sport: liberal mulicuturalism and racial triangulation of blackness, Chineseness an native American-ness in professional basketball. Ethnic and Racial Studies,35(6), 971 - 987. ISSN: $0141-9870$.

www.cbf.cz 